\title{
KEWENANGAN PEMERINTAH DAERAH PROVINSI DALAM PEMBERIAN IZIN PENGELOLAAN PERAIRAN DI WILAYAH PESISIR DAN PULAU- PULAU KECIL
}

\author{
Mawardi Khairi \\ Fakultas Hukum Universitas Borneo Tarakan \\ Email : mawardikhairi@gmail.com
}

\begin{abstract}
ABSTRAK
Lahirnya otonomi daerah telah menggeser sebagian urusan pemeritah pusat menjadi urusan pemerintahan daerah,salah satunya dalam hal perizinan di sektor kelautan,khususny di wilayah pesisir dan pulau-pulau kecil.Dalam penelitian ini permasalahan yang dibahas adalah tentang kewenangan pemerintah daerah provinsi dalam pemberian izin pengelolaan perairan di wilayah pesisir dan pulau-pulau kecil berdasarkan Undang-Undang Nomor 23 Tahun 2014 tentang Pemerintahan Daerah dan Undang-Undang Nomor 1 Tahun 2014 tentang perubahan atas Undang-Undang Nomor 27 Tahun 2007 tentang pengelolaan perairan di wilayah pesisir dan pulau-pulau kecil. Untuk menjawab rumusan permasalahan dari penelitian ini, metode penelitian yang digunakan adalah penelitian hukum yuridis atau dengan kata lain adalah jenis penelitian hukum normatif (Normatif Legal Reserch) dan dapat disebut pula dengan penelitian perpustakaan, yaitu mengkaji ketentuan hukum yang berlaku serta apa yang terjadi dalam kenyataannnya di masyarakat dengan mengkaji dari sumber-sumber literatur yang ada. Adapun tujuan penelitian ini adalah untuk mengkaji dasar hukum kewenangan pemerintah daerah provinsi dalam pemberian izin pengelolaan perairan di wilayah pesisir dan pulau-pulau kecil. Berdasarkan hasil penelitian dapat di simpulkan bahwa pemerintah daerah provinsi dalam pemberian izin pengelolaan perairan di wilayah pesisir dan pulau-pulau kecil memiliki kewenangan di dasarkan kepada UndangUndang Nomor 23 Tahun 2014,Undang-Undang Nomor 1 Tahun 2014 dan Permen Nomor 8/PERMEN-KP/2019.
\end{abstract}

Keyword: Kewenangan; Izin; Pemerintahan Daerah.

\section{ABSTRACT}

The birth of regional autonomy has shifted part of the affairs of the central government to regional government affairs, one of which is in terms of licensing in the marine sector, especially in coastal areas and small islands. In this research the problem discussed is about the authority of the provincial government in granting water management permits. in coastal areas and small islands based on Law Number 23 of 2014 concerning Regional Government and Law Number 1 of 2014 concerning amendments to Law Number 27 of 2007 concerning the management of waters in coastal areas and small islands. To answer the problem formulation of this research, the research method used is juridical legal research or in other words, a type of normative legal research (Normative Legal Research) and can also be called library research, which examines the applicable legal provisions and what happens in reality. in the community by examining existing literature sources. The purpose of this research is to examine the legal basis for the authority of the provincial government in granting permits for water management in coastal areas and small islands. Based on the results of the research, it can be concluded that the provincial government in granting permits for water management in coastal areas and small islands has the authority based on Law Number 23 of 2014, Law Number 1 of 2014 and Permen Number 8 / PERMEN-KP / 2019.

Keyword: Authority; Permission; Local government. 


\section{A. PENDAHULUAN}

Konsep negara hukum di Indonesia secara konstitusional ada sejak dideklarasikan Undang-Undang Dasar Negara Republik Indonesia Tahun 1945, di dalam Penjelasan UNDANG-UNDANGD NRI 1945 disebutkan bahwa Negara Indonesia berdasarkan atas hukum (Rechtsstaat) dan tidak berdasarkan atas kekuasaan belaka (Machtsstaat). Pembagian kekuasaan yang berlaku di Indonesia dalam hubungan antara pemerintah pusat dengan pemerintah daerah merupakan konteks pengertian yang bersifat vertikal sebagaimana yang ditegaskan dalam Pasal 18 ayat (1) UNDANG-UNDANGD NRI 1945 "Negara Kesatuan Republik Indonesia dibagi atas daerah-daerah provinsi, dan daerah provinsi itu dibagi atas kabupaten dan kota, yang tiap-tiap provinsi, kabupaten, dan kota itu mempunyai pemerintahan daerah yang diatur dengan undang-undang". Selanjutnya hubungan kewenangan antara pusat dan daerah diatur dalam undang-undang dengan memperhatikan kekhususan dan keragaman daerah. Amanah konstitusi untuk diselenggarakannya otonomi seluas-luasnya dalam kerangka Negara Kesatuan Republik Indonesia (NKRI) pada Undang-Undang Nomor 23 Tahun 2014 tentang Pemerintahan Daerah dijabarkan lebih lanjut di dalam Pasal 2 yang menyatakan Negara Kesatuan Republik Indonesia dibagi atas daerah provinsi, dan daerah provinsi itu dibagi atas daerah kabupaten dan kota. Selanjutnya Pasal 3 menegaskan bahwa daerah provinsi dan kabupaten/kota merupakan daerah dan masing-masing mempunyai pemerintahan daerah. Dalam ketentuan umum Undang-Undang Nomor 23 Tahun 2014,Pemerintah Daerah merupakan kepala daerah sebagai unsur penyelenggara pemerintahan daerah yang memimpin pelaksanaan urusan pemerintahan yang menjadi kewenangan daerah otonom. Sedangkan pemerintahan daerah adalah penyelenggaraan urusan pemerintahan oleh pemerintah daerah dan Dewan Perwakilan Rakyat Daerah menurut asas otonomi dan tugas pembantuan dengan prinsip otonomi seluas-luasnya dalam sistem dan prinsip NKRI sebagaimana dimaksud dalam Undang-Undang Dasar Negara Republik Indonesia Tahun 1945.

Ketentuan pasal 9 ayat (1) Undang-Undang Nomor 23 Tahun 2014 mengklasifikasikan urusan pemerintahan yang terdiri atas urusan pemerintahan absolut, urusan pemerintahan konkuren dan urusan pemerintahan umum. Selanjutnya dalam pasal 9 ayat (3) menyatakan bahwa urusan pemerintahan konkuren sebagaimana dimaksud pada ayat (1) adalah urusan pemerintahan yang dibagi antara Pemerintah Pusat dan Daerah Provinsi dan Daerah Kabupaten/ Kota. Pasal 9 ayat (4) menyatakan urusan pemerintahan konkuren yang diserahkan ke Daerah menjadi dasar pelaksanaan Otonomi Daerah.

Urusan pemerintahan konkuren kemudian terbagi menjadi kewenangan daerah yang terdiri atas urusan pemerintahan wajib dan urusan pemerintahan pilihan. Salah satu urusan Pemerintahan Pilihan tersebut meliputi kelautan dan perikanan (Pasal 11 ayat (1). Pasal 14 ayat (1) Undang-Undang Nomor 23 Tahun 2014 menyebutkan bahwa Penyelenggaraan Urusan Pemerintahan bidang kehutanan, kelautan, serta energi dan sumber daya mineral dibagi antara Pemerintah Pusat dan Daerah Provinsi. Dalam Pasal 14 ayat (5) disebutkan Daerah Kabupaten/ Kota penghasil dan bukan penghasil mendapatkan bagi hasil dari penyelenggaraan Urusan Pemerintahan sebagaimana dimaksud pada ayat (1), dan pada ayat (5) selajutnya diatur penentuan Daerah Kabupaten/Kota penghasil untuk penghitungan bagi hasil kelautan adalah hasil kelautan yang berada dalam batas wilayah 4 (empat) mil diukur dari garis pantai ke arah laut lepas dan/atau ke arah perairan kepulauan.

Pelaksanaan kewenangan Daerah Provinsi di laut yang disebutkan di dalam Pasal 27 ayat (1) Undang-Undang Nomor 23 Tahun 2014 di mana Daerah Provinsi diberi kewenangan untuk mengelola sumber daya alam di laut yang ada di wilayahnya. Undang-Undang Nomor 23 Tahun 2014 hanya mengatur wilayah pengelolaan yang menjadi kewenangan Daerah Provinsi 
sebagaimana disebutkan dalam Pasal 27 ayat (3) di mana kewenangan pengelolaan laut Daerah Provinsi diatur paling jauh 12 mil laut diukur dari garis pantai ke arah laut lepas dan atau ke arah perairan kepulauan. Dengan berlakunya Undang-Undang Nomor 23 Tahun 2014, terjadi perubahan kewenangan pengelolaan laut Provinsi yang semula 4-12 mil kini menjadi 0-12 mil, pengelolaan perairan yang dilakukan sebelumnya oleh Pemerintah Kabupaten/Kota diambil alih oleh Pemerintah Provinsi, salah satunya kewenangan zonasi laut yang dahulu 4-12 mil, kini menjadi 0-12 mil. Sebelumnya zonazi laut 0-4 mil menjadi kewenangan Pemerintah Kabupaten/Kota.

Dalam hal pembagian urusan bidang antara Pemerintah Pusat, Daerah Provinsi dan Daerah Kabupaten/Kota terkhusus pada sektor kelautan dan perikanan yang diatur oleh Undang-Undang tidak terdapat pemberian kewenangan pengelolaan kepada Daerah Kabupaten/Kota yang diambil alih oleh Pemerintah Pusat dan Daerah Provinsi. Dalam hal pengelolaan kelautan dan perikanannya, terdapat alasan mengapa daerah harus tetap terlibat dalam pengelolaannya, hal ini disebabkan karena daerah tidak hanya menerima menjalankan kebijakan Provinsi dan Pusat saja karena yang mempunyai tempat/wilayah pengelolaan adalah Pemerintah Kabupaten/Kota. Pendekatan penarikan semua kekuasaan/kewenangan ini merupakan resentralisasi sebagian atau sentralisasi mikro yang pada kenyataannya menjauhkan masyarakat dari pihak berwenang daerah (birokrasi) yang seharusnya menangani masalah-masalah yang ada di daerah. Paradoks mengenai jarak ini akan menyebabkan ketidakefisienan dan hambatan bagi partisipasi publik dan pengawasan terhadap pemerintah. ${ }^{1}$

Pembagian kewenangan antara Pemerintah Pusat dan Daerah hendaknya dilakukan dengan memperhatikan juga hak-hak masyarakat adat khususnya hak ulayat laut yang diakui secara konstitusional dalam Pasal 18B ayat (2) Undang-Undang Dasar NRI 1945, terutama dalam pengaturan pengelolaanya yang saat ini mendapatkan pengaturannya dalam Pasal 29 ayat (5) Undang-Undang Nomor 23 Tahun 2014.Dengan beralihnya kewenangan sektor kelautan dan perikanan ke pemerintah provinsi dan pusat,berimplikasi juga pada pemberian izin pengelolaan wilayah pesisisr dan pulau-pulau kecil sebagaimana di atur dalam Pasal 6 Peraturan Menteri Kelautan dan Perikanan Republik Indonesia Nomor 24/PERMEN-KP/2019 Tentang Tata Cara Pemberian Izin Lokasi Perairan Dan Izin Pengelolaan Perairan Di Wilayah Pesisir Dan Pulau-Pulau Kecil ayat (3) Gubernur berwenang memberikan Izin Lokasi Perairan sebagaimana dimaksud pada ayat (1) di Perairan Pesisir dan pulau-pulau kecil selain yang menjadi kewenangan Menteri sebagaimana dimaksud pada ayat (1) berdasarkan Rencana Zonasi wilayah pesisir dan pulau-pulau kecil.

Berdasarkan uraian di atas, maka dalam rangka mengharmonisasi kewenangan pemerintah daerah dalam pemberian izin baik berdasarkan Undang-Undang 23 Tahun 2014 tentang pemerintahan daerah maupun Undang-Undang Nomor 1 Tahun 2014 tentang Perubahan atas Undang-Undang Nomor 27 Tahun 2007 tentang Pengelolaan Wilayah Pesisir dan Pulau-Pulau Kecil. Maka perlu diadakan penelitian yang berjudul "Kewenangan Pemerintah Daerah Provinsi Dalam Pemberian Izin Pengelolaan Perairan Di Wilayah Pesisir Dan PulauPulau Kecil". Adapun rumusan masalah dalam penelitian ini menitik beratkan pada yaitu:

1. Bagaimanakah kewenangan pemberian izin di bidang kelautan dan perikanan khususnya wilayah pesisir berdasarkan Undang-Undang 23 Tahun 2014 tentang pemerintahan daerah?

2. Bagaimanakah kewenangan pemberian izin di bidang kelautan dan perikanan khususnya wilayah pesisirberdasarkan Undang-Undang Nomor 1 Tahun 2014 tentang Perubahan atas UndangUndang Nomor 27 Tahun 2007 tentang Pengelolaan Wilayah Pesisir dan Pulau-Pulau Kecil?

1 http://www.thejakartapost.com/news/2014/12/22/overcoming-problems-new-autonomy-era.html 


\section{B. METODE PENELITIAN}

Jenis penelitian yang akan digunakan dalam penelitian ini adalah penelitian hukum normatif. Dimana menurut Soerjono Soekamto penelitian hukum normatif adalah penelitian terhadap asas-asas hukum, sistematika hukum, sinkronisasi hukum, sejarah hukum dan perbandingan hukum $^{2}$. Adapun metode pendekatan yang digunakan dalam penelitian hukum normatif ini adalah pendekatan konsep (conceptual approach) dan pendekatan perundang-undangan (statute approach).Penulis menggunakan dua pendekatan ini karena fokus penelitian penulis pada dasar kewenangan pemerintah daerah dalam pemberian izin pengelolaan wilayah pesisir dan pulau-pulau kecil yang bersumber dari dua peraturan perundang-undangan yang berbeda.

\section{PEMBAHASAN}

\section{a. Kewenangan Pemberian Izin Di Bidang Kelautan Dan Perikanan Berdasarkan Undang-Undang 23 Tahun 2014 Tentang Pemerintahan Daerah}

Kekayaan sumber daya alam dan ekosistemnya ataupun gejala keunikan alam dan atau keindahan alam lainnya yang dimiliki oleh bangsa Indonesia merupakan karunia Tuhan Yang Maha Esa. Potensi sumber daya alam dan ekosistemnya tersebut perlu dikembangkan dan dimanfaatkan bagi sebesar-besarnya kesejahteraan rakyat sehingga tercapai keseimbangan antara perlindungan, pengawetan dan pemanfaatan lestari. Pengelolaan atas sumber daya alam di indonesia secara konstitusional berpedoman ketentuan Pasal 33 ayat (3) dengan tetap memperhatikan Pasal 28h ayat (1) Undang-Undang Dasae 1945. Pasal 33 ayat (3) UndangUndang Dasar 1945 menetapkan bahwa "bumi dan air dan kekayaan alam yang terkandung di dalamnya dikuasai oleh negara dan dipergunakan untuk sebesar-besarnya kemakmuran rakyat" sebagai bentuk pemenuhan atas hak dasar warga negara sebagaimana diamanatkan dalam pasal $28 \mathrm{~h}$ ayat (1) bahwa "setiap orang berhak hidup sejahtera lahir dan batin, bertempat tinggal, dan mendapatkan lingkungan hidup yang baik dan sehat serta berhak mendapatkan layanan kesehatan".

Sejak kebijakan otonomi daerah diberlakukan, daerah mulai memperhatikan potensi yang dimilikinya dan yang secara ekonomis dapat dikembangkan untuk meningkatkan kesejahteraan masyarakat. Beberapa daerah di Indonesia yang secara geografis memiliki wilayah pesisir dan pulau-pulau kecil menyadari betapa pentingnya pengelolaan kawasan tersebut untuk berbagai kegiatan baik yang bersifat ekonomis maupun konservasi dengan seimbang dan tepat. Kawasan pesisir dan pulau-pulau kecil memang merupakan wilayah yang memiliki keunikan tersendiri namun rentan terhadap terjadinya konflik kepentingan, ekonomi dan sosial serta berbagai persoalan lingkungan akibat pemanfaatan yang tidak didasarkan pada prinsip ekologis yang merupakan dasar pengelolaan sumberdaya secara berkelanjutan. ${ }^{3}$

Konflik kewenangan di wilayah pesisir dan pulau-pulau kecil dapat muncul ketika terjadi perubahan paradigma dalam pengelolaan sumber daya alam dalam yurisdiksi wilayah pemerintah lokal dalam kerangka desentralisasi kewenangan. Pada sumber daya alam yang sifatnya tidak lintas batas, hal tersebut

\footnotetext{
2 Soejono Soekanto dan Sri Mamudji(1994), Penelitian Hukum Normatif : Suatu Tinjauan Singkat, Jakarta : Raja Grafindo Persada, hlm. 13

3 Ambo Tuwo,(2013) Pendekatan Ekologi dalam Pengelolaan Sumber Daya Pesisir dan Laut, dalam buku Membangun Sumber Daya Kelautan Indonesia, Jakarta: IPB Press,hlml. 147.
} 
barangkali tidak akan menimbulkan masalah yang terlalu besar mengingat jurisdiksinya relatif jelas. Namun pada sumber daya yang sifatnya lintas wilayah seperti sumber daya perikanan dan kelautan, hal ini memerlukan perhatian yang cermat mengingat kemungkinan timbulnya konflik kewenangan sangat besar. ${ }^{4}$

Kewenangan pemerintah daerah dalam mengelola bidang kelautan dan perikanan berdasarkan ketentuan Pasal 11 Undang-Undang Nomor 23 Tahun 2014 Tentang Pemerintahan Daerah tentang klasifikasi urusan pemerintahan. Seperti telah diketahui bahwa sumber daya kelautan bersifat milik bersama dengan akses yang bersifat akses terbuka. Istilah milik bersama dalam sumber daya kelautan mengarah kepada pemilikan yang dilakukan di bawah kontrol pemerintah atau lebih mengarah kepada sifat sumber daya yang merupakan benda milik public. Mengingat pemanfaatan yang bersifat akses terbuka maka setiap individu merasa berhak untuk mengeksplorasi sumber daya laut. Ketika hak pemilikan belum terdefinisikan dengan jelas maka akan muncul benturan kepentingan antar individu atau kelompok, khususnya masyarakat nelayan tradisional yang secara geografis paling erat hubungannya dengan wilayah pesisir sebagi pintu gerbang menuju laut lepas.

Masyarakat tradisional adalah masyarakat perikanan tradisional yang masih diakui hak tradisionalnya dalam melakukan kegiatan penangkapan ikan atau kegiatan lainnya yang sah di daerah tertentu yang berada dalam perairan kepulauan sesuai dengan kaidah laut internasional. Masyarakat tradisional ini adalah anggota masyarakat yang bertempat tinggal tidak jauh dari pesisir yang sebagian besar berprofesi sebagai nelayan, petani (termasuk petani budi daya ikan dan rumput laut), pedagang dan profesi lainnya. Sebagai sebuah komunitas, secara umum kehidupan masyarakat yang tinggal di kepulauan bukan saja relatif terisolisi, tetapi secara tradisional juga tertinggal dibandingkan daerah sekitarnya, mobilitas vertikal masyarakat berjalan lambat, bersifat tradisional dan pilihan hidup yang tersedia umumnya sangat terbatas. Berbeda dengan masyarakat yang tinggal di daratan atau terlebih yang tinggal di kota-kota besar yang telah memiliki prasarana publik yang lengkap dan memiliki akses yang sangat tinggi terhadap informasi dan pasar. Masyarakat tradisional yang tinggal di wilayah kepulauan terbiasa hidup dalam keterbatasan fasilitas dan prasarana publik. Untuk memenuhi kebutuhan sehari-hari serta kebutuhan prasarana produksi mereka sebagian mereka penuhi dari hasil olahan sendiri, selebihnya mereka mengandalkan kiriman pasokan dari luar pulau yang datangnya tidak selalu tepat waktu karena sangat tergantung dari keberadaan alat transportasi laut dan cuaca.Tersedianya air bersih dan layanan kesehatan yang cukup dan memadai menjadi barang mewah bagi masyarakat. Selain itu sistem zonasi laut seringkali disalah tafsirkan sebagai upaya untuk membatasi ruang gerak nelayan dalam menangkap ikan dan karena kurangnya sosialisasi program pembangunan oleh pemerintah setempat sehingga masyarakat merasa tidak dilibatkan dalam perencanaan pembangunan kawasan di wilayahnya akibatnya keinginan-keinginan warga tidak terakomodir dengan baik.

Persoalan penurunan kualitas fisik lingkungan pesisir umumnya terjadi pada kosistem mangrove, terumbu karang dan padang lamun. Terumbu karang yang dalam kondisi baik saat ini tidak lebih dari 30\% sedangkan area yang mengalami degradasi hamper merata terjadi di seluruh wilayah pesisir Indonesia. Beberapa kegiatan yang diduga menjadi penyebab erosi pantai adalah kegiatan penambangan pasir laut untuk kepentingan reklamasi, pembangunan pelabuhan, jetty, marina serta pembangunan hotel dan resort. Pencemaran wilayah pesisir terjadi karena akibat dari aktivitas di darat seperti limbah industri dan rumah tangga serta pertanian. Beberapa aktivitas di laut juga menjadi salah satu penyebab kerusakan lingkungan seperti kegiatan ptransportasi laut, termasuk transportasi kapal pengangkut minyak dan

$4 \quad$ Akhmad Fauzi,(2005) Kebijakan Perikanan dan Kelautan, Jakarta: Gramedia Pustaka Utama, hlm. 51. 
kegiatan pertambangan lepas pantai. Hal-hal inilah yang menyebabkan penurunan kualitas lingkungan perairan dan estetika pantai. ${ }^{5}$

Kondisi-kondisi seperti ini perlu mendapatkan perhatian dalam pengelolaan kawasan pesisir dan pulau-pulau kecil sehingga pembangunan masyarakat yang berwawasan lingkungan dapat berjalan dengan baik dan sesuai dengan Undang-Undang Nomor 23 Tahun 2014 Tantang Pemerintahan Daerah. Pembagian kewenangan antara Pemerintah Pusat dan Daerah hendaknya dilakukan dengan memperhatikan juga hak-hak masyarakat adat khususnya hak ulayat laut yang diakui secara konstitusional dalam Pasal 18B ayat (2) Undang-Undang Dasar NRI 1945, terutama dalam pengaturan pengelolaanya yang saat ini mendapatkan pengaturannya dalam Pasal 29 ayat (5) Undang-Undang Nomor 23 Tahun 2014. Dalam pengelolaan laut di daerah dalam kajian ini, penekanannya pada penyesuaian regulasi yang terkait pengelolaan laut dengan Undang-Undang Nomor 23 Tahun 2014. Pemerataan pembangunan dan peningkatan kesejahteraan belum tercapai di Indonesia, bahkan hingga saat ini. Kekhawatiran potensi daerah dimatikan, serta Kabupaten/Kota kehilangan modal penting bagi pembangunannya perlu mendapat perhatian dan pengkajian. Oleh karena itu, diperlukan pola hubungan dan pembagian kewenangan yang tepat antara Pemerintah Pusat dan Daerah agar dapat dihindari fenomena atau ekses buruk akibat ketimpangan hubungan dan pembagian kewenangan antara Pusat dan Daerah.

Pelaksanaan kewenangan Daerah Provinsi di laut yang disebutkan di dalam Pasal 27 ayat (1) di mana Daerah Provinsi diberi kewenangan untuk mengelola sumber daya alam di laut yang ada di wilayahnya. Undang-Undang Nomor 23 Tahun 2014 hanya mengatur wilayah pengelolaan yang menjadi kewenangan Daerah Provinsi sebagaimana disebutkan dalam Pasal 27 ayat (3) di mana kewenangan pengelolaan laut Daerah Provinsi diatur paling jauh 12 mil laut diukur dari garis pantai ke arah laut lepas dan atau ke arah perairan kepulauan. Dengan berlakunya Undang-Undang Nomor 23 Tahun 2014, terjadi perubahan kewenangan pengelolaan laut Provinsi yang semula 4-12 mil kini menjadi 0-12 mil, pengelolaan perairan yang dilakukan sebelumnya oleh Pemerintah Kabupaten/Kota diambil alih oleh Pemerintah Provinsi, salah satunya kewenangan zonasi laut yang dahulu 4-12 mil, kini menjadi 0-12 mil. Sebelumnya zonazi laut 0-4 mil menjadi kewenangan Pemerintah Kabupaten/Kota.

Dalam hal pembagian urusan bidang antara Pemerintah Pusat, Daerah Provinsi dan Daerah Kabupaten/Kota terkhusus pada sektor kelautan dan perikanan yang diatur oleh UndangUndang tidak terdapat pemberian kewenangan pengelolaan kepada Daerah Kabupaten/Kota yang diambil alih oleh Pemerintah Pusat dan Daerah Provinsi. Terdapat anggapan bahwa pemberian kewenangan hanya kepada Pemerintah Daerah Provinsi tidak sesuai dengan maksud diberikannya otonomi yang seluas-luasnya kepada Daerah yang diarahkan untuk mempercepat terwujudnya kesejahteraan masyarakat melalui peningkatan pelayanan, pemberdayaan, dan peran serta masyarakat. Terlebih substansi penting dari otonomi daerah adalah pelimpahan kewenangan dari Pusat ke Daerah secara politik dan ekonomi agar pembangunan dan pertumbuhan ekonomi berlangsung secara adil dan merata di Daerah. Banyak masalah lain dapat muncul ketika hampir keseluruhan urusan daerah diurus oleh Pemerintah Pusat. Di sisi lain, pembagian kewenangan yang tidak seimbang dapat menurunkan Pendapatan Anggaran Daerah (PAD) dan juga ketika terjadi masalah di daerah terkait berbagai kebijakan yang ditangani oleh Pusat, penanganannya semua harus dilakukan oleh Pemerintah Pusat. Keresahan akan dampak negatif yang ditimbulkan Undang-Undang Nomor 23 Tahun 2014 tentang Pemerintahan Daerah, menyebabkan pemberian penguatan status kepada posisi Pemerintah Daerah Provinsi sebagai kepanjangan tangan kekuasaan Pusat sebagai suatu daerah otonomi

$5 \quad$ Ibid 
dengan menarik urusan - urusan yang selama ini ditangani oleh Pemerintah Daerah Kabupaten/ Kota dengan pertimbangan bahwa gubernur gagal mencegah abuse of power dari Pemerintah Daerah Kabupaten/Kota dan, terutama dalam masalah pertambangan, kelautan, dan kehutanan, dan juga dengan alasan dampak negatif dari abuse of power tersebut yang mengakibatkan kerusakan lingkungan yang parah akibat eksploitasi Pemerintah Daerah Kabupaten/Kota dalam rangka meningkatkan pendapatan daerah mereka.

\section{b. Kewenangan pemberian izin di bidang kelautan dan perikanan berdasarkan undang-undang no- mor 1 tahun 2014 tentang perubahan atas undang-undang nomor 27 tahun 2007 tentang pengelolaan wilayah pesisir dan pulau-pulau kecil.}

Dalam konsep pembangunan berkelanjutan ada beberapa hal yang harus diperhatikan, yaitu:

a. adanya komitmen pada keadilan dan fairness. Prioritas pembangunan seyogianya diberikan kepada masyarakat dunia yang paling miskin dan setiap keputusan hendaknya mempertimbangkan keberadaan generasi yang akan datang;

b. adanya pandangan jauh kedepan yang menekankan prinsip-prinsip precautionary untuk mencegah degradasi lingkungan;

c. pembangunan berkelanjutan mengintegrasikan, memahami, dan bertindak dalam korelasi yang kompleks antara lingkungan, ekonomi dan masyarakat. Pembangunan lingkungan, pembangunan ekonomi dan keadilan masyarakat merupakan pilar utama dalam pembangunan berkelanjutan. ${ }^{6}$

Pembangunan ekonomi harus mempertimbangkan dampak pada segi sosial dan lingkungan yang diarahkan pada: 1) pembangunan sosial yang ditujukan pada pemberantasan kemiskinan struktural di beberapa bidang, seperti ketiadaan akses pendapatan, lapangan kerja, air minum, jasa energi, pemukiman, fasilitas kesehatan, pendidikan dan lain-lain; 2) pembangunan ekonomi pembangunan ekonomi harus mengubah pola produksi dan konsumsi yang tidak menopang keberlanjutan, terutama dalam penggunaan energi yang tidak efisien dan mencemarkan, penggunaan sumber daya alam secara boros. Konsumsi juga perlu diarahkan kepada upaya daur ulang bahan kemasan dan hemat minyak karbon; 3) penyelamatan dan perlindungan ekosistem serta fungsi lingkungan dari sumber daya alam terus dijaga agar mampu menopang proses pembangunan berkelanjutan. ${ }^{7}$ Dengan karunia sumberdaya pesisir dan lautan tersebut seyogyanya masyarakat mempunyai tingkat kesejahteraan yang mapan, terutama yang bermukim di wilayah pesisir dan kepulauan. Namun sayangnya hingga saat ini sumber daya tersebut selain belum dapat dimanfaatkan secara optimal dan mengalami kerusakan akibat pemanfaatan yang tidak sesuai dengan prinsip-prinsip ekologis yang menjadi dasar pengelolaan sumberdaya alam secara berkelanjutan. ${ }^{8}$

Pada tahun 2007 Pemerintah menerbitkan Undang-Undang Nomor 27 Tahun 2007 tentang Pengelolaan Wilayah Pesisir dan Pulau-Pulau Kecil. Pemerintah telah mencermati bahwa dalam kurun waktu satu dekade terakhir ini terdapat kecenderungan terjadinya kerusakan pada wilayah pesisir dan pulau-pulau kecil karena memang wilayah tersebut memang tergolong rentan akibat aktivitas orang dalam pemanfaatan sumber daya alam serta akumulasi dari berbagai kegiatan eksploitatif yang bersifat parsial atau sektoral di wilayah tersebut atau akibat dari peraturan perundang-undangan yang terkait dengan pemanfaatan sumber daya yang tidak

6 Budi Winarno, (2013) Etika Pembangunan, Yogyakarta: Center for Academic Publising Services (CAPS) hlm. 320-321.

$7 \quad$ Ibid., mengutip pendapat Emil Salim dalam buku Ratusan Bangsa Merusak Satu Bumi, hlm, 321,

8 Aris Baso,2013 Revitalisasi Pemberdayaan Masyarakat Pesisir bagi Kesejahteraan Nelayan dalam buku Membangun Sumberdaya Kelautan Indonesia,Bogor: IPB Press,hlm 75. 
berorientasi upaya pelestarian. Kerusakan juga dapat berasal dari terjadinya bencana alam yang melanda beberapa wilayah Indonesia, khususnya di wilayah pesisir dan perairan. Pemerintah juga menyadari bahwa sementara ini kesadaran akan nilai strategis dari pengelolaan Wilayah Pesisir dan Pulau-Pulau Kecil secara berkelanjutan, terpadu, dan berbasis masyarakat relatif kurang. Kurang dihargainya hak masyarakat adat/lokal dalam pengelolaan sumberdaya Wilayah Pesisir dan Pulau-Pulau Kecil seperti pranata Sasi, Mane'e, Panglima Laot, Awigawig dan terbatasnya ruang masyarakat adat/lokal untuk berpartisipasi dalam pengelolaan sumber daya yang ada. ${ }^{9}$

Tujuan dari penyusunan Undang-Undang Nomor 27 Tahun 2007 tentang Pengelolaan Wilayah Pesisir dan Pulau-pulau Kecil ini adalah:

1) Untuk menyiapkan peraturan setingkat undang-undang mengenai pengelolaan Wilayah Pesisir dan Pulau-Pulau Kecil khususnya yang menyangkut perencanaan, pemanfaatan, hak dan akses masyarakat, penanganan konflik, konservasi, mitigasi bencana, reklamasi pantai, rehabilitasi kerusakan pesisir, dan penjabaran konvensi-konvensi internasional terkait;

2) UntukmembangunsinergidansalingmemperkuathubungankerjaantarlembagaPemerintah baik di tingkat pusat maupun daerah yang terkait dengan pengelolaan Wilayah Pesisir dan Pulau-Pulau Kecil sehingga tercipta hubungan yang harmonis dan mencegah serta memperkecilkonflikpemanfaatan dankonflikkewenangan antarkegiatandiwilayah pesisir dan pulau-pulau kecil.

3) Untuk memberikan kepastian dan perlindungan hukum serta memperbaiki tingkat kemakmuran masyarakat pesisir dan pulau-pulau kecil melalui pembentukan peraturan yang dapat menjamin akses dan hak-hak masyarakat pesisir dan anggota masyarakat lainnya yang berkepentingan, termasuk pihak pengusaha.

Ruang lingkup dari pengaturan Undang-Undang ini meliputi berbagai tahapan kegiatan dalam suatu sistem pengelolaan yang meliputi tahap perencanaan, pengelolaan, serta tahap pengawasan dan pengendalian terkait dengan berbagai aktifitas yang akan diselenggarakan di wilayah pesisir dan pulau-pulau kecil, yang meliputi daerah pertemuan antara pengaruh perairan dan daratan, wilayah daratan yang mencakup wilayah adminstrasi kecamatan dan ke arah perairan laut sejauh 12 (dua belas) mil laut yang diukur dari garis pantai ke arah laut lepas dan atau ke arah perairan kepulauan. Adapun tujuan dari pengelolaan Wilayah Pesisir dan Pulau-Pulau Kecil ini adalah:

1) Melindungi, mengonservasi, merehabilitasi, memanfaatkan, dan memperkaya sumber daya pesisir dan pulau-pulau kecil serta sistem ekologisnya secara berkelanjutan;

2) Menciptakan keharmonisan dan sinergi Antara Pemerintah dan Pemerintah Daerah dalam pengelolaan sumberdaya pesisir dan pulau-pulau kecil;

3) Memperkuat peran serta masyarakat dan lembaga pemerintah serta mendorong inisiatif masyarakat dalam pengelolaan sumber daya pesisir dan pulau-pulau kecil agar tercapai keadilan, keseimbangan, dan keberlanjutan; dan

4) Meningkatkannilai sosial, ekonomi, danbudaya masyarakatmelalui peran sertamasyarakat dalam pemanfaatan sumber daya pesisir dan pulau-pulau kecil.

Secara keseluruhan Undang-Undang Wilayah Pesisir dan Pulau-Pulau Kecil ini terdiri dari 19 (sembilan belas) bab dengan 80 pasal. Ada pranata hukum baru dalam undang-undang ini yang dikenal dengan istilah Hak Pengusahaan Perairan Pesisir (HP3). HP3 ini adalah hak atas bagian-bagian tertentu dari perairan pesisir untuk usaha kelautan dan perikanan, serta usaha lain yang terkait dengan pemanfaatan sumber daya pesisir dan pulau-pulau kecil yang

$9 \quad$ Ambo Tuwo, Op. Cit., hlm 147. 
mencakup atas permukaan laut dan kolom air sampai dengan permukaan dasar laut pada batas keluasan tertentu. HP3 ini diatur dalam Bab V tentang Pemanfaatan. HP3 ini dapat diberikan kepada orang perorangan, badan hukum yang didirikan berdasarkan hukum Indonesia dan masyarakat adat untuk jangka waktu 20 tahun dan dapat diperpanjang lagi selama 20 tahun dan seterusnya. Dalam pemberian HP3 ini, selain harus memenuhi persyaratan teknis, administrasi dan operasional, juga wajib memperhatikan kelestarian ekosistem pesisir dan pulau-pulau kecil, kepentingan masyarakat adat, kepentingan nasional serta hak lintas damai bagi kapal asing. Lingkup area yang dikecualikan dalam pemberian HP3 adalah kawasan konservasi, suaka perikanan, alur pelayaran, kawasan pelabuhan dan pantai umum. HP3 dalam UndangUndang ini disetarakan dengan hak kebendaan yang kepemilikannya dapat dibuktikan dengan adanya sertifikat yang dapat beralih dan dialihkan, serta dijaminkan dengan hak tanggungan.

Dalam perkembangannya Undang-Undang No. 27 Tahun 2007 tentang Wilayah Pesisir dan Pulau-Pulau Kecil ini dinilai oleh beberapa kalangan belum mewujudkan pendekatan Integrated Coastal Management, yang ditandai dengan tidak adanya pembaharuan atas penguasaan dan pengusahaan yang timpang dan adanya ketidaksinkronan dengan undangundang lainnya. Undang-Undang ini juga dianggap lebih mementingkan aspek investasi dan lebih pro kepada dunia usaha sehingga tidak ada ruang bagi masyarakat, khususnya masyarakat nelayan tradisional dan masyarakat adat dalam pengusulan rencana pengelolaan wilayah pesisir dan pulau-pulau kecil. Keberadaan HP3 secara substansial dianggap dapat menghalangi akses masyarakat pesisir, khususnya nelayan, terhadap sumber daya kelautan, baik yang ada di permukaan laut, badan air maupun di dasar laut. Dikhawatirkan semua akses terhadap sumber daya perairan dan kelautan nantinya akan dikuasai oleh investor/pemilik modal yang memiliki teknologi dan sanggup memenuhi persyaratan perundang-undangan sedangkan masyarakat pesisir/nelayan tradisional kembali hanya menjadi penonton karena tidak dapat bersaing.

Hal-hal inilah yang kemudian menjadi alasan bagi beberapa lembaga swadaya masyarakat dan kelompok petani serta nelayan pada Januari Tahun 2010 mengajukan permohonan Judicial Review terhadap beberapa pasal, yaitu Pasal 1 angka 4, angka 7 dan angka 18, Pasal 14 ayat (1), Pasal 16 ayat (1) dan ayat (2), Pasal 20, Pasal 23 ayat (4), ayat (5), dan ayat (6) huruf b. dalam undang-undang wilayah pesisir dan pulau-pulau kecil kepada Mahkamah Konstitusi. Selanjutnya Mahkamah Konstitusi melalui Putusan No.3/PUNDANG-UNDANG-VIII/2010 menyatakan bahwa Pasal 1 angka 18, Pasal 16, Pasal 17, Pasal 18, Pasal 19, Pasal 20, Pasal 21, Pasal 22, Pasal 23 ayat (4) dan ayat (5), Pasal 50, Pasal 51, Pasal 60 ayat (1), Pasal 71 serta Pasal 75 dalam Undang-Undang No. 27 Tahun 2007 dinyatakan bertentangan dengan Undang-Undang Dasar 1945 dan tidak mempunyai kekuatan hukum mengikat. Adapun semua perjanjian atau kontrak dan izin usaha di bidang pengelolaan wilayah pesisir dan pulau-pulau kecil yang telah ditanda tangani dan diterbitkan tetap berlaku sampai berakhirnya jangka waktu perjanjian/kontrak dan izin usaha tersebut. ${ }^{10}$

Pemerintah menilai bahwa pengelolaan wilayah pesisir dan pulau-pulau kecil selama ini belum memberikan kewenangan dan tanggung jawab Negara secara memadai atas pengelolaan perairan pesisir dan pulau-pulau kecil melalui mekanisme pemberian HP3. Namun demikian keberadaan Undang-Undang No. 27 Tahun 2007 ini dirasakan sangat strategis untuk mewujudkan keberlanjutan pengelolaan sumberdaya pesisir dan pulau-pulau kecil serta mensejahterakan masyarakat yang bertempat tinggal di wilayah pesisir dan pulau-pulau kecil. Maka dalam rangka optimalisasi pengelolaan wilayah pesisir dan pulau-pulau kecil yang sesuai dengan perkembangan kebutuhan hukum dimasyarakat, maka dilakukan perubahan atas Undang-Undang No. 27 Tahun 2007 dengan merevisi beberapa pasal di dalamnya yang 
kemudian dimuat dalam Undang-Undang No. 1 Tahun 2014 tentang Perubahan atas UndangUndang No. 27 Tahun 2007 tentang Pengelolaan Wilayah Pesisir dan Pulau-pulau Kecil dengan pertimbangan antara lain sebagai berikut: ${ }^{11}$

a. Negara bertanggung jawab atas pengelolaan wilayah pesisir dan pulau-pulau kecil dalam bentuk penguasaan kepada pihak lain, baik perseorangan atau swasta melalui mekanisme perijinan. Pemberianijinkepada pihak lain tersebut tidaklahmengurangiwewenang Negara untuk memberikan menyusun kebijakan (beleid), melakukan pengaturan (regelendaad), melakukan pengurusan (bestrsdaad), melakukan pengelolaan (beheersdaad), dan melakukan pengawasan (toezichthoudensdaad). Dengan demikian Negara masih tetap menguasai dan mengawasi secara utuh seluruh pengelolaan wilayah pesisir dan pulaupulau kecil.

b. Pengelolaan wilayah pesisir dan pulau-pulau kecil dilaukan dengan tetap mengakui dan menghormati kesatuan-kesatuan Masyarakat Hukum Adat serta hak-hak tradisionalnya sesuaidenganprinsipNegaraKesatuanRepublik Indonesia. SertamenghormatiMasyarakat Lokal dan Masyarakat Tradisional yang bermukim di wilayah pesisir dan pulau-pulau kecil.

1. Pengelolaan wilayah pesisir dan pulau-pulau kecil meliputi kegiatan perencanaan, pemanfaatan, pengawasan, dan pengendalian terhadap interaksi manusia dalam memanfaatkan sumberdaya alam pesisir dan pulau-pulau kecil serta proses alamiah secara berkelanjutan dalam upaya meningkatkan kesejahteraan masyarakat dan menjaga keutuhan NKRI. Pengelolaan tersebut.

Pengelolaan dan Perizinan Wilayah Pesisir Dan Pulau-Pulau Kecil dapat dilihat dari berbagai tahap sebagai berikut :

\section{Tahap Perencanaan}

BerdasarkanPenjelasanUmumUndang-UndangNo.7Tahun2007tentangPengelolaan wilayah pesisirdan pulau-pulaukecil dinyatakan bahwa perencanaan dilaksanakan melalui pendekatan pengelolaan wilayah pesisir dan pulau-pulau kecil secara terpadu atau yang dikenal dengan istilah Integrated Coastal Management, yang mengintegrasikan berbagai perencanaan yang disusun oleh berbagai sector terkait dan sesuai dengan tugas dan kewenangan pemerintah pusat dan daerah sehingga terjadi keharmonisan dan penguatan dalam pemanfaatan. Tahap perencanaan diatur dalam Bab IV mulai dari Pasal 7 sampai dengan Pasal 15. Berdasarkan Pasal 7, perencanaan pengelolaan wilayah pesisir dan pulau-pulau kecil terdiri atas berbagai kegiatan sebagai berikut:

a. Rencana strategis wilayah pesisir dan pulau-pulau kecil (rs-wilayah pesisir dan pulau-pulau kecil);

b. Zonasi wilayah pesisir dan pulau-pulau kecil (rz-wilayah pesisir dan pulau-pulau kecil);

c. Rencana pengelolaan wilayah pesisir dan pulau-pulau kecil (rp-wilayah pesisir dan pulau-pulau kecil); dan,

d. Rencana aksi pengelolaan wilayah pesisir dan pulau-pulau kecil (rap-wilayah pesisir dan pulau-pulau kecil).

Pemerintah Daerah berkewajiban menyusun semua rencana tersebut diatas, termas-

11 Penjelasan Umum Undang-Undang No. 1 Tahun 2014 tentang Perubahan atas Undang-Undang No. 27 Tahun 2007 tentang Pengelolaan Kawasan Pesisir dan Pulau-pulau Kecil 
uk Rencana Zonasi rinci, sesuai dengan kewenangannya masing-masing dengan melibatkan masyarakat sesuai dengan norma, standar dan pedoman yang berlaku. Selanjutnya terdapat perubahan isi dalam Pasal 14 ayat (1) yang mengatur mekanisme penyusunan rencana bahwa dalam usulan penyusunan rs-wilayah pesisir dan pulau-pulau kecil, rz-wilayah pesisir dan pulau-pulau kecil, rp-wilayah pesisir dan pulau-pulau kecil dan rap-wilayah pesisir dan pulau-pulau kecil akan dilakukan oleh Pemerintah Daerah dan Dunia Usaha. Tidak adanya pelibatan warga masyarakat lokal dan masyarakat tradisional yang bermukim di wilayah pesisir dan pulau-pulau kecil dalam penyusunan usulan rencana menjadi sorotan banyak pihak karena dianggap sebagai pengabaian hak-hak masyarakat pesisir yang seharusnya menjadi pihak yang sangat berkepentingan dalam pengelolaan wilayah pesisir dan pulau-pulau kecil. kemudian pasal 14 ayat (1) ini direvisi dalam undang-undang no. 1 tahun 2014, bahwa usulan penyusunan rs-wilayah pesisir dan pulau-pulau kecil, rz-wilayah pesisir dan pulau-pulau kecil, rp-wilayah pesisir dan pulau-pulau kecil dan rap-wilayah pesisir dan pulau-pulau kecil akan dilakukan oleh pemerintah daerah, masyarakat dan dunia usaha.

\section{Tahap Pemanfaatan}

Pemanfaatan wilayah pesisir dan pulau-pulau kecil antara lain diprioritaskan untuk kegiatan konservasi, pendidikan dan pelatihan, penelitian dan pengembangan, budidaya laut, pariwisata, usaha perikanan dan kelautan serta industri perikanan lestari, pertanian organik, peternakan dan kepentinganpertahanan dan keamanan negara. Pemanfaatan sumberdaya pesisir dan pulaupulau kecil ini dilakukan dengan menggunakan mekanisme perijinan sebagaimana diatur dalam Bab V Bagian Kesatu. Bab V inilah yang sebelumnya mengalami revisi secara radikal dengan menghapus seluruh ketentuan yang berkaitan dengan Hak Pengusahaan Perairan Pesisir (HP3) sebagai akibat dari pelaksanaan Putusan Mahkamah Konstitusi.

Selanjutnya dalam Undang-Undang No. 1 Tahun 2014 dunyatakan bahwa setiap orang yang melakukan pemanfaatan ruang dan sebagian perairan pesisir dan pemanfaatan pulaupulau kecil secara menetap diwajibkan memiliki Izin Lokasi. ${ }^{12}$ Pasal 17 Undang-Undang No. 1 Tahun 2014 mengatur mengenai pertimbangan pemberian Izin Lokasi, yaitu:

a. Pemberian Izin Lokasi disesuaikan dengan rencana zonasi wilayah pesisir dan pulau-pulau kecil,

b. Pemberian Izin Lokasi wajib mempertimbangkan kelestarian ekosistem pesisir dan pulaupulau kecil, Masyarakat nelayan tradisional, kepentingan nasional dan hak lintas damai kapal asing.

c. Izin Lokasi diberikan untuk jangka waktu dan luasan tertentu.

d. Izin Lokasi tidak dapat diberikan pada zona inti di kawasan konservasi, alur laut, kawasan pelabuhan, dan pantai umum.

Pemberian izin lokasi ini merupakan dasar dari pemberian Izin Pengelolaan. ${ }^{13}$ Izin lokasi dan Izin Pengelolaan dapat diberikan kepada orang perorang WNI, korporasi yang berbadan

12 Izin lokasi adalah izin yang diberikan untuk memanfaatkan ruang dari sebagian pesisir yang mencakup permukaan laut dan kolom air sampai dengan permukaan dasar laut pada batas keluasan tertentu dan/atau untuk memanfaatkan sebagian pulau-pulau kecil (lihat Pasal 1.18 Undang-Undang No. 1 Tahun 2014 tentang Perubahan atas Undang-Undang No. 27 Tahun 2007 tentang Pengelolaan Kawasan Pesisir dan Pulau-pulau Kecil).

13 Izin Pengelolaan adalah izin yang diberikan kepada untuk melakukan kegiatan pemanfaatan sumberdaya pesisir dan pulau-pulau kecil ((lihat Pasal 1.18A Undang-undang 
hukum Indonesia dan koperasi yang dibentuk oleh masyarakat yang memenuhi persyaratan teknis, administrasi dan operasional. Pemerintah dan Pemerintah Daerah wajib memfasilitasi pemberian Izin Lokasi dan Izin Pengelolaan kepada Masyarakat Lokal dan Masyarakat Tradisional yang akan memanfaatkan ruang dan sumberdaya perairan wilayah pesisir dan pulau-pulau kecil untuk pemenuhan kebutuhan sehari-hari. Adapun pemanfaatan ruang dan sumberdaya perairan wilayah pesisir dan pulau-pulau kecil di lingkungan wilayah Masyarakat Hukum Adat oleh Masyarakat Hukum Adat menjadi kewenangan Masyarakat Hukum Adat setempat. ${ }^{14}$

Izin Pengelolaan ini diberikan untuk kegiatan produksi garam, biofarmakologi laut, bioteknologi laut, pemanfaatan air laut selain energi, wisata bahari, pemasangan pipa dan kabel bawah laut dan pengangkatan benda muatan kapal tenggelam. Adapun pemanfaatan sumberdaya perairan wilayah pesisir dan pulau-pulau kecil dalam rangka penanaman modal asing maka ijin akan diberikan oleh Menteri Perikanan dan Kelautan setelah mendapatkan rekomendasi dari bupati atau walikota dengan tetap mengutamakan kepentingan nasional. Izin tersebut diberikan dengan syarat bahwa pemohon harus berbadan hukum perseroan terbatas, dapat menjamin akses publik, di wilayah yang tidak berpenduduk, belum ada pemanfaatan oleh masyarakat lokal, harus bekerja sama dengan peserta Indonesia, melakukan pengalihan saham secara bertahap kepada peserta Indonesia, harus melakukan alih teknologi dan memperhatikan aspek ekologi, sosial, dan ekonomi pada luasan lahan. ${ }^{15}$

Pemanfaatan ruang dari sebagian perairan pesisir dan pemanfaatan sebagian pulau-pulau kecil yang tidak sesuai dengan Izin Lokasi yang diberikan akan dikenai sanksi administrasi yang dapat berupa peringatan tertulis, penghentian sementara kegiatan, penutupan lokasi, pencabutan izin, pembatalan izin dan atau denda administratif. Pejabat yang berwenang dalam pemberian dan pencabutan ${ }^{16}$ Izin Lokasi dan Izin Pengelolaan adalah Menteri Kelautan dan Perikanan, Gubernur dan Bupati/Walikota tergantung wilayah yang menjadi kewenangannya masing-masing. Selain sanksi administratif, undang-undang juga menetapkan sanksi pidana penjara dan denda bagi pihak-pihak yang tidak memiliki Izin dan Izin Pengelolaan. ${ }^{17}$

Pasal 23 yang mengatur tentang pemanfaatan pulau-pulau kecil dan perairan di sekitarnya juga merupakan salah satu pasal yang mengalami revisi, khususnya dalam ayat (2) terdapat penambahan hingga sampai huruf (i) yaitu pemanfaatan pulau-pulau kecil dan perairan di sekitarnya dalam rangka pertahanan dan keamanan Negara. Penambahan ini sangatlah tepat mengingat Indonesia merupakan Negara kepulauan dan pulau-pulau kecil memiliki fungsi strategis dalam penetapan jurisdiksi wilayah NKRI dan keamanan Negara. Selanjutnya ketentuan ayat (4) hingga ayat (7) dalam Pasal 23 telah dihapus karena mengatur tentang HP3. Pasal 30 mengalami revisi terkait dengan perubahan zona inti pada wilayah konservasi untuk

No. 1 Tahun 2014 tentang Perubahan atas Undang-Undang No. 27 Tahun 2007 tentang Pengelolaan Kawasan Pesisir dan Pulau-pulau Kecil).

14 Lihat Pasal 20, 21, 22A dan Pasal 22B Undang-Undang No. 1 Tahun 2014 tentang Perubahan atas Undang-Undang No. 27 Tahun 2007 tentang Pengelolaan Kawasan Pesisir dan Pulau-pulau Kecil

15 Lihat Pasal 19 dan Pasal 26 A Undang-Undang No. 1 Tahun 2014 tentang Perubahan atas Undang-Undang No. 27 Tahun 2007 tentang Pengelolaan Kawasan Pesisir dan Pulau-pulau Kecil

16

Lihat Pasal 50 Undang-Undang No. 1

Tahun 2014 tentang Perubahan atas Undang-Undang No. 27 Tahun 2007 tentang Pengelolaan Kawasan Pesisir dan Pulau-pulau Kecil.

17 Lihat Pasal 71 Undang-Undang No. 1 tahun 2014 tentang Perubahan atas Undang-Undang No. 27 tahun 2007 tentang Pengelolaan Kawasan Pesisir dan Pulau-pulau Kecil 
kegiatan eksploitasi diatur lebih rinci. Dalam Bab V tentang Pemanfaatan wilayah pesisir dan pulau-pulau kecil selain diatur tentang kegiatan pemanfaatan, juga diatur kegiatan lainnya seperti konservasi, rehabilitasi, reklamasi serta larangan.

Dalam Pasal 35 diatur mengenai berbagai larangan bagi setiap orang yang secara langsung maupun tidak langsung melakukan kegiatan antara lain seperti menambang terumbu karang sehingga dapat merusak ekosistem, mengambil terumbu karang di kawasan konservasi, melakukan berbagai kegiatan yang dapat merusak ekosistem mangrove dan padang lamun, melakukan penambangan pasir dan mineral serta minyak dan gas, serta melakukan pembangunan fisik yang dapat merusak lingkungan dan merugikan masyarakat sekitarnya. Butir-butir larangan ini seharusnya seharusnya disosialisasikan dengan intensif kepada masyarakat setempat agar tidak terkena sanksi akibat dari kurang akses mereka terhadap informasi khususnya peraturan perundang-undangan yang secara khusus mengatur aktifitas di sekitar mereka.

\section{Tahapan Pengawasan dan Pengendalian}

Tahapan pengawasan dan pengendalian diatur dalam Bab VI dari Pasal 36 sampai dengan Pasal 41. Kegiatan pengawasan dan pengendalian dalam pemanfaatan wilayah pesisir dan pulau-pulau kecil dilakukan untuk menjamin terselenggaranya pengelolaan wilayah pesisir dan pulau-pulau kecil secara terpadu dan berkelanjutan. pengawasan dan pengendalian dilakukan oleh pejabat pegawai negeri sipil tertentu yang mengelola wilayah pesisir dan pulau-pulau kecil berdasarkan peraturan menteri, yang dilakukan dengan:

a. Mengadakan patroli.perondaan di wilayah pesisir dan pulau-pulau kecil, serta

b. Menerima laporan yang menyangkut perusakan ekosistem pesisir, kawasan konservasi, kawasan pemanfaatan umum dan kawasan strategis nasional tertentu.

Pasal 36 ayat (5) mewajibkan Pemerintah Pusat dan Daerah untuk melakukan pemantauan, pengamatan lapangan, dan/atau evaluasi terhadap perencanaan dan pelaksanaannya. Selanjutnya masyarakat juga dapat berperan serta dalam pengawasan dan pengendalian wilayah pesisir dan pulau-pulau kecil yang dilakukan dengan penyampaian laporan dan/atau pengaduan kepada pihak yang berwenang. Dalam rangka pengedalian dalam pemanfaatan wilayah pesisir dan pulau-pulau kecil, pemerintah berkewajiban menyelenggarakan akreditasi terhadap program pengelolaan wilayah pesisir dan pulau-pulau kecil. gubernur, bupati/walikota dan organisasi masyarakat atau kelompok masyarakat dapat mengajukan usulan akreditasi atas program pengelolaan wilayah pesisir dan pulau-pulau kecil kepada pemerintah Pusat dan Daerah sesuai dengan kewenangan masing-masing. Adapun standar dan pedoman akreditasi mencakup: a) relevansi isu prioritas; b) proses konsultasi publik; c) dampak positif terhadap kelestarian alam; d) dampak terhadap peningkatan kesejahteraan masyarakat; e) kemampuan implementasi yang memadai; dan f) dukungan kenijakan dan program Pemerintah dan Pemerintah Daerah. Dalam upaya peningkatan kapasitas para pemangku kepentingan dalam pengelolaan wilayah pesisir dan pulau-pulau kecil, undang-undang mengatur pembentukan Mitra Bahari. Mitra Bahari ini merupakan forum kerjasama antara Pemerintah dan Pemerintah daerah, perguruan tinggi, lembaga swadaya masyarakat, organisasi profesi, tokoh masyarakat dan dunia usaha. Kegiatan forum Mitra Bahari ini menurut Pasal 41 dapat berupa kegiatan pendampingan dan. atau penyuluhan, pendidikan dan pelatihan, penelitian terapan dan rekomendasi kebijakan. Kegiatan-kegiatan tersebut difasilitasi oleh Pemerintah dan Pemerintah Daerah. Hak dan kewajiban masyarakat secara khusus diatur dalam Pasal 60 .Beberapa hak masyarakat disini antara adalah hak untuk:

1) Memperoleh akses terhadap bagian perairan pesisir yang sudah diberi izin lokasi dan izin pengelolaan. 
2) Mengusulkan wilayah penangkapan ikan secara tradisional ke dalam RZ-wilayah pesisir dan pulau-pulau kecil

3) Mengusulkan wilayah Masyarakat Hukum Adat ke dalam RZ-Wilayah Pesisir Dan PulauPulau Kecil

4) Memperoleh ganti rugi

5) Memperoleh informasi dan manfaat dari pengelolaan wilayah pesisir dan pulau-pulau kecil.

6) Mengajukan laporan dan pengaduan kepada pihak yang berwenang atas kerugian yang menimpa dirinya yang berkaitan dengan pengelolaan wilayah pesisir dan pulau-pulau kecil, termasuk mengajukan ganti rugi atas peristiwa tersebut.

7) Mengajukan gugatan kepada pengadilan terhadap berbagai masalah wilayah pesisir dan pulau-pulau kecil dan mendapatkan pendampingan dan bantuan hukum sesuai dengan peraturan yang berlaku.

Selain mengatur tentang hak, Pasal 60 ini juga mengatur tentang kewajiban masyarakat dalam wilayah pesisir dan pulau-pulau kecil, diantaranya adalah:

a. Memberikan informasi berkenaan dengan pengelolaan wilayah pesisir dan pulau-pulau kecil

b. Menjaga, melindungi dan memelihara kelestarian wilayah pesisir dan pulau-pulau kecil.

c. Menyampaikan laporan terjadinya bahaya pencemaran dan/atau kerusakan lingkungan di wilayah pesisir dan pulau-pulau kecil

Secara berimbang undang-undang ini juga memberikan kewajiban kepada pemerintah dan pemerintah daerah untuk mengakui, menghormati dan melindungi hak-hak masyarakat adat, masyarakat tradisional dan kearifan lokal atas wilayah pesisir dan pulau-pulau kecil yang telah dimanfaatkan secara turun temurun dan menjadikan pengakuan hak-hak masyarakat adat, masyarakat tradisional dan kearifan lokal tersebut sebagai acuan dalam pengelolaan wilayah pesisir dan pulau-pulau kecil. Pasal ini berpotensi akan menjadi macan kertas mengingat tidak dilengkapi dengan mekanisme dan bentuk pengakuan tersebut. Seharusnya secara jelas dinyatakan bahwa pengakuan dan perlindungan tersebut diberikan dalam suatu peraturan perundang-undangan. Dalam hal pemberdayaan masyarakat diatur dalam Pasal 64 ayat (2) telah mengalami perubahan dengan memberikan rincian beberapa kebutuhan mendasar yang memang sangat dibutuhkan oleh masyarakat, khususnya masyarakat pesisir dan nelayan tradisional, bahwa Pemerintah dan Pemerintah Daerah berkewajiban mendorong kegiatan usaha masyarakat melalui peningkatan kapasitas, pemberian akses teknologi dan informasi, permodalan, infrastruktur, jaminan pasar dan asset ekonomi produktif lainnya.

Undang-undang Nomor 7 Tahun 2007 yang kemudian diubah dengan Undang-Undang Nomor 1 Tahun 2014 telah dilengkapi dengan mekanisme penyelesaian sengketa, gugatan perwakilan, proses penyidikan, sanksi administrasi dan sanksi pidana. Sanksi administrasi dalam Pasal 71 Undang-Undang No. 7 Tahun 2007 telah disesuaikan dan terdapat penambahan 2 (dua) ayat. Adapun bentuk sanksi administrasi dalam undang-undang ini dapat berupa: a) peringatan tertulis; b) penghentian sementara kegiatan; c) penutupan lokal; d) pencabutan izin; e) pembatalan izin dan atau f) denda administratif. Ketentuan sanksi pidana dalam Pasal 75 telah disesuaikan dengan pemberatan sanksi bagi setiap orang yang memanfaatkan ruang dari sebagian perairan pesisir dan pemanfaatan sebagian pulau-pulau kecil yang tidak memiliki izin lokasi sebagaimana ketentuan Pasal 16 ayat (1) dipidana penjara paling lama 3 (tiga) Tahun dan denda paling banyak Rp 500.000.000,- (lima ratus juta rupiah). Ketentuan sanksi sebelumnya hanya berupa pidana kurungan paling lama 6 (enam) bulan atau denda paling banyak Rp 300.000.000,- (tiga ratus juta rupiah). Diharapkan pemberatan sanksi ini dapat membrikan efek jera. Namun yang paling penting adalah keberanian dan ketegasan pihak yang 
berwajib untuk menegakkan ketentuan undang-undang tentang wilayah pesisir dan pulaupulau kecil kepada pihak-pihak yang melanggar.

\section{KESIMPULAN}

Kewenangan Daerah Provinsi di laut di dalam Pasal 27 ayat (1) Undang-Undang Nomor 23 Tahun 2014 di mana Daerah Provinsi diberi kewenangan untuk mengelola sumber daya alam di laut yang ada di wilayahnya. Undang-Undang Nomor 23 Tahun 2014 hanya mengatur wilayah pengelolaan yang menjadi kewenangan Daerah Provinsi sebagaimana disebutkan dalam Pasal 27 ayat (3) di mana kewenangan pengelolaan laut Daerah Provinsi diatur paling jauh 12 mil laut diukur dari garis pantai ke arah laut lepas dan atau ke arah perairan kepulauan. Dengan berlakunya Undang-Undang Nomor 23 Tahun 2014, terjadi perubahan kewenangan pengelolaan laut Provinsi yang semula 4-12 mil kini menjadi 0-12 mil, pengelolaan perairan yang dilakukan sebelumnya oleh Pemerintah Kabupaten/Kota diambil alih oleh Pemerintah Provinsi, salah satunya kewenangan zonasi laut yang dahulu 4-12 mil, kini menjadi 0-12 mil. Sebelumnya zonazi laut 0-4 mil menjadi kewenangan Pemerintah Kabupaten/Kota. Berdasarkan Undang-Undang No. 27 Tahun 2007 Pemerintah Daerah diberikan kewenangan menerbitkan izin lokasi dan izin pengelolaan wilayah perairan dan pulau-pulau terkecil sebagaimana di atur dalam pasal 18A Undang-undang No. 1 Tahun 2014 tentang Perubahan atas Undang-Undang No. 27 Tahun 2007 tentang Pengelolaan Kawasan Pesisir dan Pulau-pulau Kecil.

\section{DAFTAR PUSTAKA}

\section{Buku:}

Abdul Latif (2005) Hukum dan Peraturan Kebijaksanaan ( Beleidsregel) pada Pemerinthan Daerah,Cetakan I, UII Press,Yogyakarta.

Akhmad Fauzi,(2005) Kebijakan Perikanan dan Kelautan, Jakarta: Gramedia Pustaka Utama. Ambo Tuwo, (2013) Membangun Sumber Daya Kelautan Indonesia,Jakarta: IPB Press Aminuddin Ilmar, (2014) Hukum Tata Pemerintahan, Jakarta Kencana Press

Aris Baso(2013),Revitalisasi Pemberdayaan Masyarakat Pesisir bagi Kesejahteraan Nelayan dalam buku Membangun Sumberdaya Kelautan Indonesia,Bogor: IPB Press

Budi Winarno, (2013) Etika Pembangunan, Yogyakarta: Center for Academic Publising Services (CAPS)

C.F Strong, 2011 Konstitusi-Konstitusi Politik Modern, Nusa Media, Bandung,

Ganjong, 2007Pemerintahan Daerah Kajian Politik dan Hukum, Bogor, Ghalia Indonesia,

Gouw Giok Siong, 1955Pengertian Tentang Negara Hukum, Jakarta, Keng Po,

Irfan Fachrudin, 2004.Pengawasan Peradilan Administrasi terhadap Tindakan pemerintah, Cetakan I, Bandung, Alumni,

Juniarso Ridwan, dkk, 2012Hukum Administrasi Negara dan Kebijakan Pelayanan Publik, Bandung,Nuansa Cendekia,

Miriam Budiardjo, 1998 Dasar-Dasar Ilmu Politik, Jakarta, Gramedia Pustaka Utama,

N.M Spelt dan J.B.J.M ten Berge disunting Philips M Hadjon, 1993 PengantarHukum Perizinan, Yuridika,

Philipus M Hadjon., 1994 Pengkajian Ilmu Hukum Dogmatik (Normatif), 
Surabaya,FakultasHukum Universitas Airlangga,

Philipus M.Hadjon, 2005, Hukum Administrasi Negara, Yogyakarta, Gadjah Mada University Press,

Prajudi Atmosudirjo, 2006, Hukum Administrasi Negara, Jakarta,Ghalia Indonesia,

Ridwan HR, 2006, Hukum Administrasi Negara, Jakarta, Rajawali Pers,

Rochmat Soemitro, 1976,Peradilan Administrasi Dalam Hukum Pajak Di Indonesia,Cetakan ke-IV,PT. ERESCO,Jakarta - Bandung,

SF. Marbun, 1987, Pokok-Pokok Hukum Administrasi Negara, Yogyakarta, Liberty,

Soehino, 1998Ilmu Negara,Cetakan III,Yogyakarta, ,Liberyty

Soejono Soekanto dan Sri Mamudji, 1994 Penelitian Hukum Normatif : Suatu Tinjauan Singkat, Jakarta : Raja Grafindo Persada,

Utrecht, 1963, Pengantar Hukum Administrasi Negara Indonesia, Jakarta,PT. Ichtiar,

Y. Sri Pudyatmoko, 2009, Perizinan Problem dan Upaya Pembenahan, Jakarta: Grasindo,

\section{Jurnal:}

EnyKusdarini,Arti Penting dan Implementasi Hukum Perizinan Dalam Bidang Lingkungan Hidup Di Indonesia, Jurnal Civics, Vol. 2 No. 2 ,2005

\section{Peraturan Perundang-Undangan:}

Undang-Undang Dasar NRI Tahun 1945

Undang-Undang Nomor 23 Tahun 2014 tentang Pemerintahan Daerah

Undang-Undang No. 1 Tahun 2014 tentang Perubahan atas Undang-Undang No. 27 Tahun 2007 tentang Pengelolaan Kawasan Pesisir dan Pulau-pulau Kecil

Peraturan Pemerintah Nomor 62 Tahun 2010 Tentang Pemanpaatan Pulau-Pulau Kecil Terluar

Peraturan Menteri Nomor 8/Kempen-KP/2019 Tentang Penatausahaan Izin Pemanfaatan Pulau-Pulau Kecil Dan Perairan di sekitarnya dalam rangka PMA dan Rekomendasi Pemanfaatan Pulau-Pulau Kecil dengan Luas Di Bawah 100 Km 2 (Seratus Kilometer Persegi) 